\title{
Sources of $\mathrm{Cd}$ in Cocoa crop Soils of Santander, Colombia
}

\author{
CARME HUGUET $^{1 *}$, VALENTINA JOYA-BARRERO ${ }^{1}$, IDAEL \\ FRANCISCO BLANCO-QUINTERO ${ }^{2}$ AND DANIEL BRAVO ${ }^{3}$ \\ ${ }^{1}$ Geoscience Department, Los Andes Univeristy, Bogotá, \\ Colombia,m.huguet@uniandes.edu.co; ${ }^{2}$ Departamento de \\ Cienias de la tierra y medio ambiente, Universidad de \\ Alicante, España, if.blanco@ua.es; ${ }^{3}$ Corporación \\ Colombiana de Investigación Agropecuaria, Mosquera, \\ Colombia,dbravo@agrosavia.co.
}

Cacao is the second crop of production and export in Colombia. Starting January 2020, the European Union enforced a new regulation on the content of Cadmium $(\mathrm{Cd})$ in cacao-derived products. This is of great concern for colombian producers since cacao in the area of Santader present high $\mathrm{Cd}$ levels ${ }^{1}$ that would hindering export. The high content of $\mathrm{Cd}$ in these the grains of cacao is direcly linked to high concentrations of $\mathrm{Cd}$ in soils ${ }^{2}$.

In order to determine the origin of the $\mathrm{Cd}$ in soils we analized, 23 soils, 12 source rocks and 2 fertilizer (inorganic and organic) samples collected at differet farms in the study area using XRF. We also dtermined soil $\mathrm{pH}$ and organic matter and carbonate content all of which have been linked to $\mathrm{Cd}$ content in soils ${ }^{2}$. Petrological analysis of rocks and soil was performed to determine the mineral origin of the metal. In all the soils, rocks and fertilizer samples, high levels of $\mathrm{Cd}$ were found. The great majority of them exceeded by far the limits stated by the international regulation.

The results relate the concentration of $\mathrm{Cd}$ in the soil mainly with the organic matter content, the addition of organic fertilizers, the primary $\mathrm{Cd}$ contents in rocks and the $\mathrm{Ca}$ content of soils. In order to reduce the concentration of $\mathrm{Cd}$ in the final product only low $\mathrm{Cd}$ concentration fertilizers should be used. Additionally, farmers use cocoa plant debry to fertilize the crops which recicles the $\mathrm{Cd}$ absorbed by the plant back to the soil and may explain the strong correlation observed between $\mathrm{Cd}$ levels and orgaic matter. In the future the project aims to identify other strategies in order to make $\mathrm{Cd}$ less available for the plant, like adding $\mathrm{Mg}$ or carbonates that can potentially sequester $\mathrm{Cd}$ reducing adsortion by the cacao plant.

[1] Bravo, D., Pardo-Díaz, S., Benavides-Erazo, J., RengifoEstrada, G., Braissant, O., \& Leon-Moreno, C. (2018). Journal of applied microbiology, 124(5), 1175-1194.

[2] Engbersen, N., Gramlich, A., Lopez, M., Schwarz, G., Hattendorf, B., Gutierrez, O., \& Schulin, R. (2019). STOTEN, 678, 660-670. 